Fanum

Sociológico

\section{Forum Sociológico}

Série II

$30 \mid 2017$

Internet e ativismos em saúde

\title{
Grupos de entreajuda de doentes com hepatite $C$ no ciberespaço
}

Self-help groups of patients with hepatitis $C$ in the cyberspace

\section{Marta Maia}

\section{(2) OpenEdition \\ Journals}

Edição electrónica

URL: https://journals.openedition.org/sociologico/1772

DOI: 10.4000/sociologico. 1772

ISSN: 2182-7427

Editora

CICS.NOVA - Centro Interdisciplinar de Ciências Sociais da Universidade Nova de Lisboa

Refêrencia eletrónica

Marta Maia, «Grupos de entreajuda de doentes com hepatite C no ciberespaço», Forum Sociológico [Online], 30 | 2017, posto online no dia 30 dezembro 2017, consultado o 30 março 2022. URL: http:// journals.openedition.org/sociologico/1772 ; DOI: https://doi.org/10.4000/sociologico.1772 


\title{
GRUPOS DE ENTREAJUDA DE DOENTES COM HEPATITE C NO CIBERESPAÇO SELF-HELP GROUPS OF PATIENTS WITH HEPATITIS C IN THE CYBERSPACE
}

\author{
Marta Maia \\ Instituto Universitário de Lisboa, Escola de Ciências Sociais e Humanas, Pólo do ISCTE-IUL do Centro em Rede de \\ Investigação em Antropologia (CRIA-IUL)
}

\begin{abstract}
Resumo
Este artigo descreve experiências de pessoas com hepatite $C$, como expressam a sua vivência da doença em grupos franceses de entreajuda na internet, como esta doença e o seu tratamento afetam o seu quotidiano e também a sua identidade, e como se percecionam em relação aos não-doentes. Faz-se também uma reflexão sobre a identidade das pessoas que utilizam estes grupos de entreajuda online na sua gestão da doença (os "hépatants"). O ciberespaço é um lugar onde os doentes podem buscar informações e expressar-se. Os diálogos que aí se tecem tornam-se para muitos uma narrativa terapêutica.
\end{abstract}

Palavras-chave: hepatite $\mathrm{C}$, doença, internet, narrativas

\begin{abstract}
This article describes the experience of French people who have a hepatitis $\mathrm{C}$, how they feel the disease and express their experiment online; how the disease and its treatment influence the daily life of people infected by the virus of hepatitis $C$ and also their identity, the way they are considering themselves, and how they are considering the non-sick people. This article also reflects on the personal identity, the feeling of belonging to a group, the "hépatant" people, as they call themselves. Forums on internet are a space where the sick persons can pick up information, find help and express themselves. The dialogue on those forums becomes, for many of them, a therapeutic narrative.
\end{abstract}

Keywords: hepatitis C, illness, internet, narratives

\section{Introdução}

A hepatite $C$ é uma doença viral transmissível pelo sangue e por via materno-fetal. Esta doença infeciosa representa um grave problema de saúde pública a nível mundial pela sua prevalência e pela morbilidade e mortalidade a ela associadas (Mohd Hanafiah et al., 2013). A Organização Mundial de Saúde declarou como um dos seus objetivos estratégicos a eliminação das hepatites virais, particularmente a $\mathrm{C}$ e a $\mathrm{B}$, responsáveis pela maioria dos casos de hepatite, enquanto ameaça à saúde pública, até 2030 (WHO, 2016).

Cerca de 170 milhões de pessoas no mundo são portadoras do vírus da hepatite $\mathrm{C}$ (VHC). A prevalência na Europa é de aproximadamente 1,1\% da população. Estima-se que apenas um terço das pessoas infetadas estejam diagnosticadas (European Centre for Disease Prevention and Control, 2016). É, pois, um problema de saúde pública, social e económico relevante.

A severidade da doença hepática ligada ao VHC é variável, mas pode provocar cirrose ou mesmo cancro do fígado. Devido às complicações da doença, a infeção por VHC tem um impacto económico elevado na perspetiva da sociedade (Anjo et al., 2014).

Até 1992, não eram tomadas as medidas necessárias para impedir a transmissão viral através das doações de sangue e atos médicos invasivos, pelo que algumas infeções não estão associadas a práticas de risco, nomeadamente o consumo de drogas injetáveis (Cimbidhi, 2003).

Até 2016, o tratamento da hepatite C consistia numa associação de dois medicamentos: o interferão 
peguilado e a ribavirina. Esta terapêutica apresentava cerca de $50 \%$ de índice de cura, mas os seus efeitos adversos eram importantes (depressão, febre, dores musculares, dores de cabeça, cansaço, náuseas, perda de peso, perturbações do sono, perturbações psicológicas, entre outros), e 15\% dos doentes abandonavam o tratamento (Pawlotsky e Dhumeaux, 2004).

A hepatite perturba a vida quotidiana (Fédération SOS Hepatites, 2003; Körner, 2010; Rei et al., 2017). Além de provocar frequentemente cansaço crónico, obriga a um acompanhamento médico regular, que por sua vez reaviva o sentimento de se ser doente. Esta doença apresenta poucos sintomas mas o seu tratamento teve até recentemente muitos efeitos indesejáveis, tornando-a sintomática justamente no momento da tentativa de cura, o que cria um paradoxo, na vivência da doença, entre o processo de entrada na cura e o estado de debilidade causado pelo tratamento médico.

Existem em França várias associações de doentes com hepatites. A invenção do termo "hépatant" para designar os membros das associações de doentes deve-se a um membro da associação SOS Hépatites. O termo alargou-se depois a todas as pessoas que vivem com uma hepatite.

Atualmente existe um tratamento com muito poucos efeitos indesejáveis e uma taxa de cura muito elevada: acima dos 90\% (Varaldo, 2016). Esta pesquisa não deixa, no entanto, de ter interesse, pois o que é relevante na análise do comportamento dos "hépatants", e que pode ser transposto a outras situações de doença, é a rede de relações de apoio que se cria entre os doentes, que entram em contacto uns com os outros por meio de plataformas existentes na internet (blogs, fóruns, grupos, redes sociais).

Numa sociedade em que a internet ocupa um lugar cada vez maior enquanto fonte de informação e meio de comunicação, os espaços de diálogo online adquirem uma importância crescente ao possibilitarem um meio de expressão de si, de partilha de experiências com os outros e de discussão dos significados da saúde e da doença, e das suas múltiplas experiências (Akrich e Méadel, 2004).

O ciberespaço serviu de lugar de observação destas últimas, por corresponder a um espaço de socialização cada vez mais utilizado pelos doentes na gestão da vivência quotidiana da doença crónica, que permite uma conexão com os outros, o que muitos doentes consideram importante, sobretudo aqueles que estão em tratamento, cujas necessidades de apoio e compreensão urgem nesse período biográfico específico. A palavra, da narrativa ao diálogo, é procurada e vivida como terapêutica (Gagnon, 1999).

O objetivo da pesquisa foi o de perceber 0 que as pessoas exprimem a respeito das suas experiências da doença nestes espaços de comu- nicação virtuais e anónimos. A internet permite o anonimato, o que leva as pessoas a exprimirem-se bastante livremente sobre as suas vivências, impressões, angústias, etc.

A recolha de dados foi feita em França, entre 2005 e 2008, em dois espaços virtuais, o Hépatites \& Cie e o hepatites.net. Entrei em contacto, através destes ciberespaços, com dez pessoas, cinco mulheres e cinco homens, com idades compreendidas entre os 35 e os 55 anos, para realizar entrevistas semiestruturadas com o intuito de completar e aprofundar a compreensão das suas biografias enquanto doentes crónicos. As entrevistas foram realizadas na área metropolitana de Paris, de 2005 a 2006. Foram gravadas com o acordo das pessoas inquiridas, cujos nomes foram alterados por razões de confidencialidade. As entrevistas forneceram narrativas mais detalhadas sobre alguns aspetos biográficos, nomeadamente os percursos terapêuticos, sobre os quais as pessoas entrevistadas foram questionadas. Os testemunhos incluídos no presente artigo foram traduzidos do francês.

O quadro teórico que sobressaiu como mais adequado à análise do material recolhido foi o da teoria narrativa (Bruner, 1987; Good e Good, 1993; Holstein e Gubrium, 2000; Hydén, 1997; Kleinman, 1988; Laplantine, 1999; Ricoeur, 1985; Rowan e Cooper, 1999).

\section{"Trocar cromos" "entre si"}

O ciberespaço permite o encontro entre doentes, conheçam-se eles pessoalmente ou não, que partilham vivências comuns da doença e possibilita a criação de redes de interajuda. São espaços onde se constroem narrativas, expressões simbólicas que dizem o drama social da doença, o processo experiencial da doença, a construção do seu significado e a tomada de decisões na vida do doente (Langdon, 2001).

A confrontação dos dados recolhidos revelou realidades compartilhadas pela maioria das pessoas entrevistadas, além da diversidade dos seus percursos biográficos. Todos os entrevistados procuraram nos espaços de diálogo online um apoio interpares, que descrevem como muito importante na sua gestão da doença.

Encontrar "pares" é encontrar pessoas com a mesma doença e, por conseguinte, com experiências similares, com conhecimentos para partilhar e informações para trocar. Como dizia uma das pessoas entrevistadas, é um lugar onde se pode "trocar cromos". O encontro com os "pares" apazigua, ao longo dos diálogos que se tecem com os outros, a doença enquanto intruso no corpo. A linguagem da doença inscreve-se neste corpo, que é carregado de sentido e que a antropologia tenta apreender através de uma abordagem que tome em conta os 
significados e as lógicas dos comportamentos (Augé e Herzlich, 1984).

O aparecimento da doença suscita a necessidade de a nomear, compreender a sua origem, dar-lhe sentido através de uma rede semântica (Good, 1998), um conjunto de noções e símbolos que estruturam a experiência da doença, assim como a necessidade, para o indivíduo, de recompor a sua identidade (Bury, 1982; Charmaz, 1983). No quadro de existências singulares, o indivíduo tenta dar coerência aos acontecimentos através da palavra. A narrativa explica o que aconteceu e o que está acontecendo, informa-nos acerca do modo como o doente poderá gerir a doença e fornece instrumentos e materiais para se redefinir com o novo elemento que é o diagnóstico da doença crónica (Langdon, 2001). Com efeito, para muitos dos doentes lidos e ouvidos, não se trata apenas de ter uma doença mas de se ser "hépatant".

A identidade é composta por uma configuração de elementos identitários que se mobilizam em função das circunstâncias. Num processo biográfico movente, o sujeito recompõe permanentemente a sua identidade (Dortier, 1998; Kaufmann, 2004). Cada indivíduo participa na vida social de vários grupos, tem várias identidades, ou seja, a sua identidade pessoal enraíza-se numa pertença a várias identidades: nação, região, classe social, sexo, geração, grupo profissional, etc. (Berting, 2001). A doença é um dos ingredientes que compõem a identidade. Ela é, segundo os nossos entrevistados, um elemento com uma importância relevante para a construção da identidade pessoal, tornando-se também um elemento de identificação com os outros doentes, podendo mesmo reunir em seu torno uma identidade grupal, a dos "hépatants".

Esta investigação desenvolveu-se em França, onde surgiu uma palavra original para designar os portadores de uma hepatite crónica, inventado por um ativista da associação SOS Hépatites: "hépatant", com $h$, como hepatite, neologismo que se confunde com o termo épatant, sem $h$, que significa espantoso (Maia, 2008). Os "hépatants" que frequentam o meio associativo e/ou os espaços de diálogo sobre as hepatites estão unidos pela consciência de uma doença comum, pela partilha das suas histórias de vida e pelas relações e diálogos que estabelecem entre eles através do ciberespaço (Maia, 2008).

Existem termos frequentemente utilizados pelos "hépatants"1, dificilmente compreensíveis numa primeira abordagem. As abreviaturas utilizadas, assim como certas expressões particulares, parecem sublinhar a distinção entre os membros dos espaços virtuais de diálogo em torno das hepatites (os "hépatants") e "os outros" (Maia, 2008).

O que leva estes indivíduos a procurarem ciberespaços sobre as hepatites é sobretudo a busca de informação e a necessidade de diálogo com pessoas que têm a mesma doença, consideradas como pares. A necessidade de partilhar informações, experiências e sentimentos com outros doentes nasce ou reforça-se com o início do tratamento. Com efeito, os "hépatants" falam dos membros que já passaram pela experiência frequentemente penosa do tratamento como "iniciados". Nota-se em alguns discursos uma valorização daqueles que já levaram a cabo vários tratamentos. Exibe-se por vezes o número de tratamentos como provas de coragem e elogiam-se aqueles que as possuem. Transforma-se assim essa experiência dolorosa em instrumento de valorização de si. Também são alvo de elogios e felicitações aqueles que acedem à cura, como se o doente fosse o único responsável por esse feito. O doente procura ser (re)valorizado (Taïeb et al., 2005).

Frequentemente, o sentimento de estar doente surge apenas com o primeiro tratamento, pois a doença permanece impercetível durante vários anos, sem sintomas muito visíveis. O tratamento, isto é, o facto de tomar medicamentos, por um lado, e de se sentir mal fisicamente e/ou psicologicamente devido aos seus efeitos indesejáveis, por outro lado, torna a doença tangível, traz consigo o sentimento de estar doente, e mesmo de ser doente.

"[O primeiro tratamento] era ainda com o interferão três vezes por semana, mas tive doses de indução, tive doses de dez milhões de unidade durante quinze dias, e aí, efetivamente, estava tão fraca que realmente senti-me doente e aceitei o rótulo de ser doente." (Mireille, 45 anos, em tratamento)

A necessidade de contactar com outros doentes prende-se igualmente com o sentimento de ser incompreendido e a ideia de que os outros, os não-doentes, não podem entender o que significa ter hepatite $\mathrm{C}$ e sobretudo estar sob tratamento.

"As outras pessoas não percebem nada... As pessoas que não têm uma hepatite, não Ihes podes falar disso, quer dizer, é como com qualquer outra doença, apercebes-te rapidamente de que as outras pessoas não conseguem entender aquilo que te está a acontecer... Como queres que compreendam? Não é possível. É necessário teres vivido tu mesmo as coisas, porque... Bom, além disso, eu não tinha ar de doente, estás a ver... Além disso, durante o tratamento, engordei muito, por isso... Sim, podia-se ver que tinha engordado, mas tinha ar de quem está boa de saúde. (...) Por isso, as pessoas, se não ficas muito magra e toda... Estás a ver?" (Aline, 50 anos, curada) 
Existe um sentimento de pertença a um grupo que partilha uma experiência comum, a crença que os outros "não sabem", "não podem entender" o que significa ter esta doença, e um desejo de comunicar com os membros desses grupos de autoajuda no ciberespaço.

A incompreensão dos outros é explicada pela incapacidade de ter plena consciência do sofrimento quotidiano do doente, a dificuldade em apoiá-lo a longo prazo, tendo, além disso, de fazer frente a um sentimento frustrante de incapacidade para resolver as dificuldades que a doença coloca, sobretudo aos doentes em tratamento. Neste contexto, os doentes afirmam que os únicos capazes de os compreender são os outros doentes, o que os leva a procurar associações de doente e espaços de diálogo com outros doentes no ciberespaço. Opera-se, por conseguinte, uma reconfiguração relacional, a par com uma recomposição identitária.

\section{Narrativas terapêuticas}

O facto de se sentirem entre pares torna o verbo dos doentes mais livre e oferece-Ihes o conforto da certeza de serem compreendidos. A narrativa ganha sentido por endereçar-se a alguém que partilha uma experiência comum. Ancorados nessa comunidade, os outros doentes podem contribuir para a narrativa pessoal e participar no trabalho de tecelagem dos acontecimentos numa trama com sentido e coerência. A narrativa em diálogo influencia o modo como o indivíduo perceciona a sua existência e constrói a sua narrativa. As questões colocadas pela doença são produzidas para si, para os outros e com os outros (Quinche, 2005). Além disso, a imediação deste meio de comunicação possibilita um trabalho de configuração do sentido dos acontecimentos biográficos no presente. No ciberespaço, a apresentação de si como doente e do seu caminho terapêutico é imediatamente comentada pelos outros membros do grupo online e edifica-se ao longo das mensagens escritas, acompanhando os acontecimentos biográficos.

A pertença a um grupo de doentes ou uma associação é uma originalidade do prestador de autocuidados em que o doente crónico se torna. Este deseja quebrar o isolamento e procura um eco das suas experiências e dúvidas. Quando o apoio social é insuficiente, as associações prestam uma ajuda considerável, fornecendo serviços sociais e jurídicos, informação sobre a doença e os tratamentos, apoio psicológico e emocional, assim como um lugar de sociabilidade e encontro (Adam e Herzlich, 2002).

Existem muitas estruturas associativas no contexto das doenças crónicas. Elas têm como objetivo principal a informação e o apoio das pessoas afetadas pelas hepatites. O diálogo com pessoas que compartilham uma experiência comum traz ainda o benefício da luta contra um sentimento de isolamento e a autoestigmatização, pacificando a relação do paciente com a sua doença (Fainzang, 1989; 2001). As associações estão envolvidas na produção e disseminação de conhecimento sobre as doenças e problemas de saúde; desempenham um papel ativo na emergência e consolidação da mobilização coletiva em torno de questões de saúde; e são reconhecidas como atores da democracia sanitária, juntamente com os poderes públicos, os profissionais de saúde e os agentes económicos (Akrich e Méadel, 2007; Akrich et al., 2008).

A maioria das pessoas inquiridas procuram apoio quando o tratamento se revela eminente. Este acarreta o sentimento de estar/ser doente, devido aos seus efeitos adversos. É nesse momento que os doentes procuram mais informação sobre a doença e o tratamento e procuram estabelecer laços com outros doentes. Muitas vezes a entrada no tratamento corresponde à descoberta dos espaços virtuais de diálogo, até aí desconhecidos. O doente vê nesses espaços possibilidades de ligação ao mundo, mas não um mundo qualquer, o mundo dos "hépatants", os únicos capazes de o compreender no que diz respeito à vivência da doença. Como notou Gagnon (1999), a ideia segundo a qual só os que viveram uma determinada experiência a podem compreender dá significado aos grupos de entreajuda que reúnem pessoas com um problema comum. A entreajuda pela palavra entre doentes confere assim ao grupo a sua singularidade.

"Dei-me conta de que há muitas pessoas no mesmo caso que eu (...) Era a primeira coisa que eu fazia de manhã ao acordar. Ligava o computador e lia as novas mensagens no sítio hepatites.net. Estava aberto em permanência. Por isso, passava o tempo entre o computador, a cama e o sofá. (...) Durante o tratamento, há momentos em que dás em doida... Pensas: 'Não é possível, estou farta, isto tem de acabar, vou parar o tratamento, não posso mais, porque estou de rastos, porque não tenho mais vida', coisas assim. E aí, todas as pessoas com quem já falaste, estão aí todas para te dizer: 'Tens de te aguentar, isso vai passar...' e tudo o que precisas... E, além disso, é verdade que ajudar as pessoas, em todo o caso tentar ajudar, permite... Estás no teu cantinho, quase no teu pequeno feto, e interessas-te pelos outros, isso permite voltares a interessar-te pelos outros, estás a ver? Porque uma pessoa a quem falaste com o teu coração uma vez, porque sentias que não estava bem, depois tens vontade de saber como é que ela está. Por isso, apetece-te continuar a seguir as histórias, e isso permite não se sentir completamente fora do mundo. Porque é esse o problema, é 
que te sentes completamente fora do mundo. $E$ isso [os espaços de diálogo online] mantém uma relação." (Aline, 50 anos)

O ciberespaço permite ao doente narrar a sua experiência da doença e o seu percurso biográfico de doente. A escrita torna-se uma "salvação" (Laplantine, 1984). A narrativa dá coerência aos acontecimentos dispersos, dá-Ihes sentido e contribui para a construção da identidade pessoal. Narrar é reconfigurar a perceção do vivido inserindo os acontecimentos numa trama significativa (Laplantine, 1984; Ricoeur, 1990).

O ciberespaço permite uma narrativa-diálogo. Aí, a construção do sentido opera-se através de uma narrativa dialógica, onde o discurso é endereçado, partilhado e discutido. A relação que se estabelece com os outros doentes torna esta forma de narrativa particular porque dialógica (Quinche, 2005). Além disso, o facto de ler as histórias dos outros doentes, dos pares, permite ao indivíduo melhor situar-se e definir a sua própria história de vida.

\section{A cura}

A cura é o fim da doença. Por isso implica uma fase difícil e uma renovação ou uma mudança, tanto para os que fazem o luto da doença e se separam de tudo aquilo que recorda a doença como para os que permanecem ligados a ela. A cura é encarada como uma situação difícil porque se viveu anos de um determinado modo, indo ao médico regularmente, não bebendo álcool, etc., com a consciência da presença de um vírus.

"Depois [da cura], tudo desaparece. (...) De repente, o teu inquilino vai-se embora!" (Catherine, 45 anos)

A cura exige também uma recomposição identitária. A mudança no quotidiano como na perceção de si que ela acarreta traz com ela uma perturbação identitária que o indivíduo tenta resolver. Usando a terminologia dos entrevistados, o "doente curado" passa, no seu percurso biográfico de doente, por duas mudanças que têm implicações identitárias: toma consciência do seu estado de doente - com o tratamento e os efeitos adversos que acarreta - e deixa de estar/ser doente - com a cura, depois do tratamento. Assim, um dos entrevistados, para quem o tratamento constituiu uma primeira alteração do seu quotidiano, a entrada num processo de cuidados de saúde e uma mudança da perceção que tinha de si, iniciou uma psicoterapia não durante o tratamento, como lhe aconselhara o médico, mas depois da cura. A cura corresponde a mais uma mudança de higiene de vida e de estatuto (de doente para curado).

"Parei com o álcool no início do tratamento... Porque fiz quarenta anos (...) e tam- bém porque começava o tratamento quinze dias depois. (...) Pensei: 'Preciso começar a mudar ou encontrar soluções... Estou gravemente doente...' Pesava cem quilos para um metro e setenta, tinha os cabelos compridos, oleosos... Não era o mesmo. Por isso decidi aproveitar. Pensei: 'Bom, vou estar doente durante um ano, é melhor mudar tudo.' Deixei de fumar. Fumava desde a adolescência. Por isso, disse para comigo: 'Mais vale sofrer durante um ano, pôr tudo no mesmo cesto, mas pelo menos fico desembaraçado (...) O tratamento vai acabar por limitar-me, mais vale aproveitar...' Havia como que uma ideia de reparação. Há quinze anos que andava cansado por causa do vírus da hepatite $C$, cansado cronicamente... Pensei: 'Bom, é uma oportunidade para arranjar isto tudo'. A priori, livrar-se do vírus é uma reparação, tanto melhor reparar realmente, reparar-se totalmente, como se repara um veículo, pronto. Tanto melhor reparar tudo ao mesmo tempo. (...) Voltei para casa dos meus pais, onde cresci. Para o meu quarto de criança. Talvez seja simbólico... Além disso, isso acompanha a psicoterapia, retomamos tudo o que se passou na infância (...) É uma segunda vida que começa, talvez... Volto ao ponto de partida..." (François, 42 anos)

A fase de tratamento é vivida como um momento ambíguo, que desestabiliza o quotidiano, a imagem de si, das suas relações com os outros, da perceção que tem dos outros, e ao mesmo tempo traz a esperança da cura, de uma melhor qualidade de vida e de uma esperança de vida mais longa. É também um momento no qual o sujeito se sente "mergulhado na doença" e que descreve como um "parêntesis na vida". Ora, ao sair desse parêntesis, precisa de recompor a sua identidade, enquanto não-doente e por vezes também enquanto ser social que trabalha, tem relações sociais, tem uma vida sexual ativa, etc. Deve integrar novos elementos identitários para dar coerência à representação de si, integrando a experiência da doença. Um processo de recomposição da identidade que é, aliás, concomitante com um processo de recuperação física, quando o doente recupera o seu peso, os seus cabelos, o equilíbrio da sua pele, a sua vitalidade, o equilíbrio psicológico, a atividade sexual, etc., depois do tratamento.

Quando "sai da doença", o indivíduo pode então sentir um "vazio". Porque "perdeu" o vírus, os laços sociais decorrentes do estatuto de doente, tais como o médico, o psicólogo e os doentes dos grupos de autoajuda, e também uma parte da sua identidade, a identidade de doente.

" - Como te sentiste depois do tratamento e de ficar curada? 
- Isso é justamente uma coisa um bocado esquisita, acredita, porque durante o meu tratamento, senti-me um pouco como... Estava doente mas, ao mesmo tempo, tinha muito apoio, psicologicamente, tinha o psiquiatra que me acompanhava, tinha o psicólogo, havia o meu gastrenterologista que me seguia de perto, mesmo o meu médico de família escutava-me e isso... Bom, além disso, havia o sítio hepatites.net que me tem realmente... Quer dizer, estava o tempo todo no sítio... Aquilo realmente ajudou-me muito... E, por isso, no fim do tratamento, de repente... É como se tu... Tudo para de repente... O tratamento para, por isso, é suposto não precisares mais de ajuda... És completamente desapossado da tua vida... É um pouco como quando paras com a droga, quer dizer... Quando és alcoólico, por exemplo, o espírito é preenchido por aquilo que te está a acontecer, quer o álcool, quer a droga ou, portanto, a hepatite... Eu só pensava nisso, estás a ver, estava aqui para me tratar e pensava apenas nisso. E, por isso, de repente, é suposto sentires-te bem porque está tudo acabado, mas tu já não tens nada com que preencher a tua vida... Isso chocou-me, era muito esquisito..." (Aline, 50 anos)

Ainda que haja variações individuais quanto à vivência da doença, do tratamento e da cura, há certamente um "antes" e um "depois" da hepatite, como dizia um dos indivíduos entrevistados que, após o diagnóstico da hepatite, deixou de consumir álcool, durante o tratamento divorciou-se, no final do tratamento começou uma psicoterapia e, uma vez curado, alterou os seus hábitos alimentares e mudou de residência. A cura representa, pois, outra rutura biográfica, após a do anúncio da doença e a do início do tratamento. É um momento difícil que pode também causar sentimentos de culpa. Uma culpabilidade por ter "conseguido" a cura quando outros "não conseguem".

A narrativa no ciberespaço permite obter um sentimento de controlo da situação difícil, fornecendo mesmo estratégias para a sua resolução, mediante a interação com os pares que servem de apoio psicológico e social, além de funcionarem como recetores empáticos e compreensivos das mensagens do doente.

A cura pode gerar um sentimento de perda dos benefícios secundários - aquilo que aparece como benéfico no estatuto de doente - para o doente habituado a ser recebedor de cuidados e objeto de uma particular atenção por parte dos que o rodeiam, a ter apoios sociais suplementares, etc. (Schützenberger, 2009). Ora, a narrativa online ajuda o indivíduo a resolver o conflito provocado pela cura enquanto rutura biográfica, prolongando o espaço de construção de sentido e de recomposição identitária durante a fase de transição entre o estatuto de doente e o de curado.

\section{Ser ou não ser doente}

Nas representações sociais, a doença está associada ao patológico (Canguilhem, 1966), à incapacidade e ao risco de morte (Kleinman, 2002), o que provoca, para o doente, uma desvalorização de si e mesmo uma ansiedade perante a morte (Herzlich e Pierret, 1984). O anúncio da doença crónica é, pois, frequentemente vivido como uma rutura biográfica. O doente começa por rejeitar este novo estatuto anunciado pela presença de uma doença crónica, que, como um carimbo aposto no corpo, modifica a imagem de si (Adam e Herzlich, 2002). Por vezes, o doente não entra imediatamente num processo de cuidados de saúde e recusa desempenhar o papel do paciente, isto é, dar início a um acompanhamento médico e a uma terapêutica, temendo que a doença invada toda a sua existência e a sua identidade pessoal (Evans, Barer e Marmor, 1996).

"Durante anos meti a cabeça na areia, ou seja, não queria fechar-me nessa coisa, no inferno médico. Continuei a viver sabendo muito bem que devia estar infetado. Tomava as precauções habituais...

Naquela altura, era toxicodependente. Não emprestava a minha seringa, mas frequentava apenas pessoas (...) E é verdade que não me via sair daquele esquema, porque sair daquele esquema ter-me-ia obrigado a fazer um teste e a ser confrontado com a realidade (...) Não ia ver o médico porque negava a realidade e acabei por ir parar às urgências." (Boris, 48 anos)

A desdramatização da doença é outra das reações face ao anúncio do diagnóstico, que ajuda o indivíduo a gerir tanto a doença nos seus aspetos corporais, como em relação a este novo elemento biográfico e identitário: o estatuto de doente crónico. O doente pode ainda inverter a escala de valores associada à doença crónica e percecioná-la como "algo de bom", percebendo-a sob um ângulo diferente do infortúnio (Taïeb et al., 2005).

"A mim, a doença trouxe-me muitas coisas boas. Sou certamente muito diferente do que seria... Penso ser uma pessoa melhor do que teria sido... Porque a escala dos valores torna-se muito diferente... Eu sempre fui muito tolerante, mas agora sou-o mesmo, realmente. E depois, porque nada é grave." (Virginie, 41 anos, coinfetada VIH-VHC) 
A fase do tratamento é vivida como um momento ambíguo porque está entre o ser doente e o já não ser doente, ou o doente curado, quando o doente acede à cura. Além disso, por um lado, o tratamento desestabiliza a pessoa, o seu quotidiano, a imagem de si, as relações com os outros e a perceção que tem dos outros, por outro lado, encarna a esperança da cura e de uma melhor qualidade de vida. É também um momento em que se encontra "mergulhado na doença", que obriga a uma reorganização do quotidiano e, simultaneamente, a integrar, a nível identitário, a experiência passada da doença crónica. O diálogo com outros doentes ajuda o indivíduo nesse processo.

\section{Conclusão}

Para o doente, o corpo não é apenas um objeto físico, é uma parte essencial do seu Eu (Good, 1998). A doença altera a perceção de si e a experiência da doença deixa marcas na construção identitária (Laplantine, 1986).

O trabalho de escrita que é feito no ciberespaço participa nas representações da doença e nos modos de se relacionar com os outros, e serve também de "salvação pela escrita", segundo a expressão de Laplantine (1984), permitindo assumir uma "experiência-limite" (Laplantine, 1986) que participa na definição, experiência e gestão da doença, assim como na reconfiguração da identidade do doente.

Após a cura, alguns doentes esforçam-se por expulsar a doença do seu quotidiano, não a relembrando, operando uma rutura e um renascimento. Outros, ao libertarem-se do vírus, sentem um vazio e a necessidade de permanecer em contacto com doentes, nomeadamente através de grupos de entreajuda, de modo a dar uma continuidade biográfica ao estatuto de doente e a negociar esta outra rutura biográfica que é a cura, de modo a integrar este novo elemento, a ausência da hepatite, o luto da doença, na definição de si e na sua vida. Neste sentido, algumas pessoas definem-se como "doentes curados". Esta forma de se definir corresponde a uma estratégia para impedir que a rutura biográfica desestabilize a identidade pessoal, na medida em que esta última decorre do facto de se percecionar como idêntico a si mesmo no tempo (Tap, 1980). Além disso, ajudar os outros doentes através da mobilização associativa concede uma utilidade ao sofrimento vivido, que se torna por isso benéfico. A experiência da doença ganha, assim, sentido e valor.

De notar, por fim, que o ativismo de alguns doentes lhes oferece um papel social e um conhecimento sobre a doença que lhes confere poder. Com efeito, associações como a Fédération SOS Hépatites tornam-se atores sociais com poder de decisão e de ação no campo da saúde. O trabalho de apropriação do saber médico das associações de doentes contribui para uma melhor gestão da doença, conferindo ao doente instrumentos teóricos de controlo de situações difíceis decorrentes da doença, assim como o sentimento de ser ator da sua própria existência. Local de fornecimento de dados objetivos sobre a doença, de partilha de informações, de criação de laços sociais, de relações interpares, e de conquista de autonomia, os grupos de doentes representam um elemento fundamental na representação, vivência e gestão da doença.

\section{Notas}

1 São exemplos disso os termos, abreviações e expressões seguintes: transa = transaminases; $E S=$ efeitos secundários; $t t t=$ tratamento; $I N F=$ interferão; riba = ribavirina; $Q D V=$ qualidade de vida; $M G=$ médico generalista; INF lambda = interferão não peguilado.

\section{Referências bibliográficas}

ADAM, P. e C. Herzlich (2002 [1994]), Sociologie de la maladie et de la médecine, Paris, Nathan.

AKRICH, M. e C. Méadel (2004), "Prendre ses médicaments/prendre la parole: les usages des médicaments par les patients dans les listes de discussion électroniques", Sciences sociales et Santé, 20 (1), pp. 89-116.

AKRICH, M. e C. Méadel (2007), "De l'interaction à l'engagement: les collectifs électroniques, nouveaux militants dans le champ de la santé", Hermès, La Revue, 47 (1), pp. 145-153.

AKRICH, M., et al. (2008), The Dynamics of Patient Organizations in Europe, Paris, Presses de l'École des Mines.

ANJO, J., et al. (2014), "O impacto da hepatite C em Portugal", Jornal Português de Gastrenterologia, 21 (2), pp. 44-54.

AUGÉ, M. e C. Herzlich (1984), Le sens du mal. Anthropologie, histoire, sociologie de la maladie, Paris, Éditions des Archives Contemporaines.

BERTING, J. (2001), "Identités collectives et images de I'Autre", Hermès, La Revue, 30 (2), pp. 41-58.

BRUNER, J. (1987), "Life as Narrative", Social Research, $54(1)$, pp. 11-32.

BURY, M. (1982), "Chronic Illness as Biographical Disruption", Sociology of Health and Illness, 4 (2), pp. 167-82.

CANGUILHEM, G. (1966), Le normal et le pathologique, Paris, Presses Universitaires de France.

CHARMAZ, K. (1983), "Loss of Self. A Fundamental Form of Suffering in the Chronically Illness", Sociology of Health and Illness, 5 (2), pp. 168-95.

CIMBIDHI, J. (2003), Les hépatites virales $A, B, C .$. , Adrenais, Les Asclépiades.

DORTIER, J.-F. (1998), "L'individu dispersé et ses identités multiples", in J.-C. Ruano-Borbalan (org.), 
L'identité. L'individu, le groupe, la société, Auxerre, Sciences Humaines.

EUROPEAN CENTRE FOR DISEASE PREVENTION AND CONTROL (2016), Annual Epidemiological Report 2016 - Hepatitis C, Estocolmo, ECDC. Disponível em: http://ecdc.europa.eu/en/healthtopics/hepatitis-b/Pages/Annual-epidemiological-report-2016. aspx (Consultado em 22/02/2017).

EVANS, R., et al. (orgs.) (1996), Être ou ne pas être en bonne santé. Biologie et déterminants sociaux de la maladie, Montreal, Les Presses de I'Université de Montréal/John Libbey Eurotext.

FAINZANG, S. (1989), Pour une anthropologie de la maladie en France, Paris, Éditions de l'École des Hautes Études en Sciences Sociales.

FAINZANG, S. (2001), "L'anthropologie médicale dans les sociétés occidentales. Récents développements et nouvelles problématiques", Sciences Sociales et Santé, 19 (2), pp. 5-27.

FÉDÉRATION SOS HÉPATITES (2003), "Vivre avec une hépatite virale", Bulletin SOS Hépatites, (22), pp. 3-6.

GAGNON, É. (1999), "La communication, I'autre, I'indicible. De l'entraide des malades", Anthropologie et Sociétés, 23 (2), pp. 61-78.

GOOD, B. (1998), Comment faire de l'anthropologie médicale? Médecine, rationalité et vécu. Le Plessis-Robinson, Institut Synthélabo.

GOOD, B. e M.-J. D. Good (1993), "Au mode subjonctif. La construction narrative des crises d'épilepsie en Turquie", Anthropologie et Sociétés, 17 (1-2), pp. 21-42.

HERZLICH, C. e J. Pierret (1984), Malade d'hier, malades d'aujourd'hui. De la mort collective au devoir de guérison, Paris, Payot.

HOLSTEIN, J. A. e J. F. Gubrium (2000), The Self We Live By. Narrative Identity in a Postmodern World, Nova Iorque, Oxford University Press.

HYDÉN, L.-C. (1997), "Illness and Narrative", Sociology of Health and IIlness, 19(1), pp. 48-69.

KAUFMANN, J.-C. (2004), L'invention de soi. Une théorie de l'identité, Paris, Armand Colin.

KLEINMAN, A. (1988), The Illness Narrative. Suffering, Healing and the Human Condition, Nova Iorque, Basic Books.

KLEINMAN, A. (2002), "Santé et stigmate. Note sur le danger, l'expérience morale et les sciences sociales de la santé", Actes de la Recherche en Sciences Sociales, 143 (1), pp. 97-99.

KÖRNER, H. (2010), "Negotiating Treatment for Hepatitis C: Interpersonal Alignment in the Clinical Encounter", Health, 14 (3), pp. 272-291.
LANGDON, E. J. (2001), "A doença como experiência: o papel da narrativa na construção sociocultural da doença", Etnográfica, 5 (2), pp. 241-260.

LAPLANTINE, F. (1984), "Corps malades et salut par l'écriture dans la littérature autobiographique contemporaine", Lumière et Vie, (166), pp. 29-43.

LAPLANTINE, F. (1986), L'anthropologie de la maladie, Paris, Payot.

LAPLANTINE, F. (1999), Je, nous et les autres, Paris, Le Pommier.

MAIA, M. (2008), Paroles hépatantes, Paris, L'Harmattan/ /Éditions Pepper.

MOHD HANAFIAH, K., et al. (2013), "Global Epidemiology of Hepatitis C Virus Infection: New Estimates of Age-Specific Antibody to HCV Seroprevalence", Hepatology, 57 (4), pp. 1333-1342.

PAWLOTSKY, J.-M. e D. Dhumeaux (2004), Hépatite C Paris, Editions Médicales et Scientifiques.

QUINCHE, F. (2005), "Récits sur la maladie. Maladie et récits de vie. D'un paradigme narratif à un paradigme dialogique", Revue Éthique et Santé, 2 (2), pp. 82-87.

REI, A., et al. (2017), "Health-Related Quality of Life in Portuguese Patients with Chronic Hepatitis C", Jornal Português de Gastrenterologia, 24 (2), pp. 68-78.

RICOEUR, P. (1985), Temps et récit, Vol. 3: Le temps raconté, Paris, Seuil.

RICOEUR, P. (1990), Soi-même comme un autre, Paris, Seuil.

ROWAN, J. e M. Cooper (1999), The Plural Self. Multiplicity in Everyday Life, Londres, Sage.

SCHÜTZENBERGER, A. A. (2009), Vouloir guérir, Paris, Desclée de Brouwer.

TAÏEB, O., et al. (2005), "Donner un sens à la maladie: de l'anthropologie médicale à l'épidémiologie culturelle", Médecine et maladies infectieuses, 35(4), pp. 173-185.

TAP, P. (org.) (1980), Identité individuelle et personnalisation. Production et affirmation de l'identité, Toulouse, Privat.

VARALDO, C. (2016), "Qual a possibilidade de cura com os novos medicamentos para hepatite $C$ ? ALEH 2016". Disponível em: http://hepato.com/p_ cura/030_cura_port.php\#sthash.YPKgMojl.dpuf.

WORLD HEALTH ORGANIZATION (WHO) (2016), Draft Global Health Sector Strategies: Viral Hepatitis, 2016-2021 (Report EB138/30), Report by the Secretariat. Disponível em: http://apps. who.int/gb/ebwha/pdf_files/EB138/B138_30-en.pdf?ua $=1$.

Recebido a 01/03/2017. Aceite para publicação a 24/10/2017.

Marta Maia (maia_marta@hotmail.com). Instituto Universitário de Lisboa, Escola de Ciências Sociais e Humanas, Pólo do ISCTE-IUL do Centro em Rede de Investigação em Antropologia (CRIA-IUL). Av. Forças Armadas, Edifício ISCTE-IUL, 1649-026 Lisboa, Portugal. 